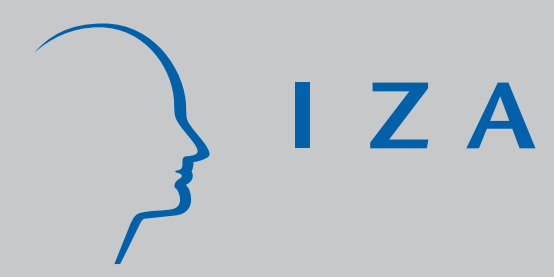

IZA DP No. 1696

On the Post-Unification Development of Public and Private Pay in Germany

Axel Heitmueller

Kostas Mavromaras

J uly 2005 


\title{
On the Post-Unification Development of Public and Private Pay in Germany
}

\author{
Axel Heitmueller \\ London Business School \\ and IZA Bonn
}

Kostas Mavromaras

University of Aberdeen

and IZA Bonn

Discussion Paper No. 1696

July 2005

IZA

P.O. Box 7240

53072 Bonn

Germany

Phone: +49-228-3894-0

Fax: +49-228-3894-180

Email: iza@iza.org

\begin{abstract}
Any opinions expressed here are those of the author(s) and not those of the institute. Research disseminated by IZA may include views on policy, but the institute itself takes no institutional policy positions.

The Institute for the Study of Labor (IZA) in Bonn is a local and virtual international research center and a place of communication between science, politics and business. IZA is an independent nonprofit company supported by Deutsche Post World Net. The center is associated with the University of Bonn and offers a stimulating research environment through its research networks, research support, and visitors and doctoral programs. IZA engages in (i) original and internationally competitive research in all fields of labor economics, (ii) development of policy concepts, and (iii) dissemination of research results and concepts to the interested public.
\end{abstract}

IZA Discussion Papers often represent preliminary work and are circulated to encourage discussion. Citation of such a paper should account for its provisional character. A revised version may be available directly from the author. 


\section{ABSTRACT}

\section{On the Post-Unification Development of Public and Private Pay in Germany}

German post-unification in the 1990s is a period that was marked by substantial economic change, part of which was East German wages building towards the much higher West German levels. This paper studies the public-private pay gap in the fast changing economic and political environment of the 1990s using panel estimation techniques which control for unobserved individual heterogeneity. It shows that, while the overall pay gap between public and private sector stayed remarkably constant in the West, earnings differences in the East increased threefold in the late 1990s resulting in a substantial wage premium in the public sector. It is suggested that this premium is a result of the politically induced gap between pay and actual productivity. Furthermore, results vary greatly by gender indicating significantly larger female earnings differentials. Several institutional and political arguments are presented to explain this phenomenon.

JEL Classification: J78, J31

Keywords: public-private sector pay differential, decomposition, Germany

Corresponding author:

Axel Heitmüller

London Business School

Regent's Park

London, NW1 4SA

United Kingdom

Email: aheitmueller@london.edu 


\section{Introduction}

This paper investigates the relationship between public and private sectors in Germany in the 1990s. One concern regarding public and private wages and employment is the degree to which the competitiveness of the private sector may be influenced by the employment and wage policies of the public sector. It is widely recognised that the influence of political processes on the determination of wages and employment is much stronger in the public than in the private sector. The opposite holds for the influence of labour market forces.

Regional differences in public sector pay and employment can have profound consequences for the general competitiveness of a region. The crucial comparison is that between public and private sector pay levels. If the public sector pays above the private sector, the latter may feel compelled to raise private rates in order to match the public sector and retain its labour force. This could raise private sector costs and impinge on regional competitiveness.

Traditionally, governments have transferred resources to less competitive regions in order to address the resulting problems of unemployment and deprivation generated by such lack of competitiveness (Henley and Thomas, 2001). The scope of such transfers has been curtailed by the European Union. As a result, the focus of current policy for governments throughout the European Union is upon restoring the competitiveness of regions with higher deprivation and unemployment. The purpose of this paper is to inform the debate on regional competitiveness and provide some evidence as to the extent and the impact of pay differences between the public and private sectors in the German economy. The paper uses micro data from the German Socioeconomic Panel (GSOEP) for the period of 1991 to 2001.

This paper concentrates on two major events which influenced German competitiveness in the 1990s and which set Germany apart from all other European Union economies. The first event was East-West German re-unification, an event clearly unique to Germany within the European Union. The second event was privatisation which has been happening throughout most European Countries in the 
last 20 years, but which has been greatly influenced in Germany by re-unification. German re-unification started in 1990. Its political, social and economic repercussions are still felt all too strongly a decade and a half later. Given the large differences between East and West incomes, one of the mainstays of political re-unification was to establish fairness in pay between all German employees. Looking back at the start of re-unification in the very early 1990s, it is not clear if the economic repercussions of the relevant policies were either well thought out or well understood at the time of their implementation.

The second factor which influenced German competitiveness in the 1990s is privatisation. Two main privatisation waves can be traced in Germany in the 1990s. The first wave took place in the East only, immediately after re-unification where thousands of firms previously owned by the state were privatised by Treuhand, an institution specifically introduced in order to implement the privatisation of East German firms, most of which were state-owned in 1990. The second wave started in the mid 1990's, covered both East and West Germany, and involved some of the most important state-owned firms, such as railways, telecommunications, and mail services.

The two processes of re-unification and privatisation, alongside with their interactions makes the study of the influence of the public sector on competitiveness in Germany a unique and very interesting case. Of particular interest is the way in which the conflict between the political objective of East-West German convergence and the economic objective of preserving and enhancing German competitiveness has been played out, especially because of public-private sector differences in pay negotiations in the 1990s.

The scenario presented in the paper is simple and compelling. Upon re-unification a massive and politically unacceptable East-West pay gap was present. Also, a large number of East German firms that belonged to the state faced problems regarding trading within their new (western) environment. The objectives of (i) individual pay East-West convergence and (ii) transfer of ownership from the (East) state to the private sector dominated the first years after re-unification. The outcome was that the East-West pay gap was reduced sharply in the first half of the 1990s and that a large 
number of previously (East German) state-owned firms either became private or stopped trading. The public and the private sectors responded to the challenge very differently. The East/West pay gap in the public sector was reduced to less than $20 \%$ by 1995 and stayed at around this level for the rest of the 1990s. By contrast, the East/West pay gap in the private sector was reduced a lot less by 1995 (to about 40\%) and also stayed roughly unchanged till the end of the 1990s. Part of this difference can be explained by the fact that many private sector firms left the Federal Employment agreements (Burda and Schmidt, 1997). At the same time the strong convergence of the public sector and the weak convergence of the private sector increased the publicprivate pay differential in the East considerably from around $10 \%$ in the first half of the 1990s to around 30\% in the later 1990s. The public-private differential in the West during the same period stayed largely unchanged at about $10 \%$.

As this paper shows these differentials were not due to the composition of the EastWest and public-private human capital. Several causes for wage changes after reunification have been proposed in the literature (Sinn 1995, Dustmann and van Soest 1997) of which this paper finds possible support for the proposition that different negotiation avenues and patterns have determined the different outcomes for the public and the private sectors. More specifically, the paper finds supporting evidence for the proposition that whilst the public sector in the East was protected by the negotiations of the (West German public sector) unions, for various political and economic reasons, the same protection was not forthcoming for the private sector in the East by the negotiations of the (West German private sector) unions. As a result the public sector premium in the East increased from -2\% in the 1991-95 period to $18 \%$ in the 1996-2001 period. Crucially, the conventional warnings that would accompany an increasing public sector pay premium in terms of the public sector crowding out the private sector do not seem to be borne out by the analysis of this paper. This is (i) because the public sector has been decreasing in size in the East and (ii) because there is sufficiently high unemployment in the East for any additional labour demand by the private sector to not be able to generate upward pressures in the general wage level. Of course, in a tighter labour market with excess labour demand, crowding out through different convergence rates could have been a possibility.

The paper calculates the conditional public-private wage differential in four different regimes: West (East), before (after) privatisation. This exercise is carried out 
separately for males and females as there are very strong empirical indications of gender differences. The paper uses panel fixed effects estimation and controls for time-invariant individual unobserved heterogeneity and sample selection. The publicprivate wage gap is decomposed using Oaxaca-Ransom decompositions. The public sector pay premium (i.e. where public pay is higher than private pay over and above what could be explained by individual differences in human capital characteristics) is calculated and its statistical significance is assessed using bootstrapping techniques. The paper is organised as follows. Section 2 contains a description of the institutional background and history. Section 3 presents the data. Section 4 presents the econometric model and discusses estimation issues. Section 5 discusses results and concludes. Full estimation results and descriptive statistics are included in an Appendix.

\section{Institutional background and history}

\subsection{Public and private wages}

Re-unification presented the West German economy with a new partner of much lower productivity and wages. Wages in the East were around 7\% of those in the West at the outset of re-unification (Sinn, 1995). In 1991, East German wages were renegotiated in order to establish some form of comparability of costs and productivity as well as fairness within the whole of a united Germany. The idea was that conflicting equity and competitiveness objectives should be somehow reconciled. Great emphasis was placed on the objective of equity, where it was considered desirable that the same wage should be paid for a job carried out in the West as in the East. It was immediately obvious in 1991 that, in order to bring East- West equality of pay about, a large increase in wages in the East would have been necessary. As a consequence, through legislative measures, the East German wage level reached $80 \%$ of the West German level within only five years after re-unification. It is not clear whether it was obvious at that time that such a policy could have serious repercussions regarding the competitiveness of former East Germany. At the time of re-unification it was clear that while the human capital of East Germany was competitive and of a considerably high standard, the physical capital stock of the 
former East German economy was exceedingly aged and unable to compete within the western economic sphere (Franz and Steiner 1999).

Although there are different interpretations in the literature as to why things happened as they did (see Sinn 1995, Dustmann \& van Soest 1997, Burda \& Schmidt 1997), a brief summary of what happened runs as follows. Whereas West Germany had a longstanding history of wage settlement negotiations (and the trade union infrastructure to support them), East Germany in 1990 was far less well equipped to perform such a vital economic function. Although West German public and private employees wages were settled separately, and to a degree by different organisations (just under one half of German state employees, the Beamten, have no right to negotiate their wages, as they are directly determined by the state), the development of public and private wages was closely linked with one another (Dustmann \& van Soest 1997). By contrast, East German employees in 1990 emerged from a political situation where most employees and most economic activity were meant to have been part of a large public sector. Upon re-unification in 1990, there were two main candidates to choose from for negotiating wage settlements in East Germany: the East German trade unions or the West German trade unions. The East German trade unions suffered a credibility deficit, principally due to their strong past links with the former East German government (Franz \& Steiner 1999). Hence, almost by default, negotiations on behalf of the employees of the East German private industry were carried out by the West German trade unions. The stated objective was to achieve a fair wage and a fair competitive playing field between the two parts of Germany. 
Figure 1: Wages by sector and region

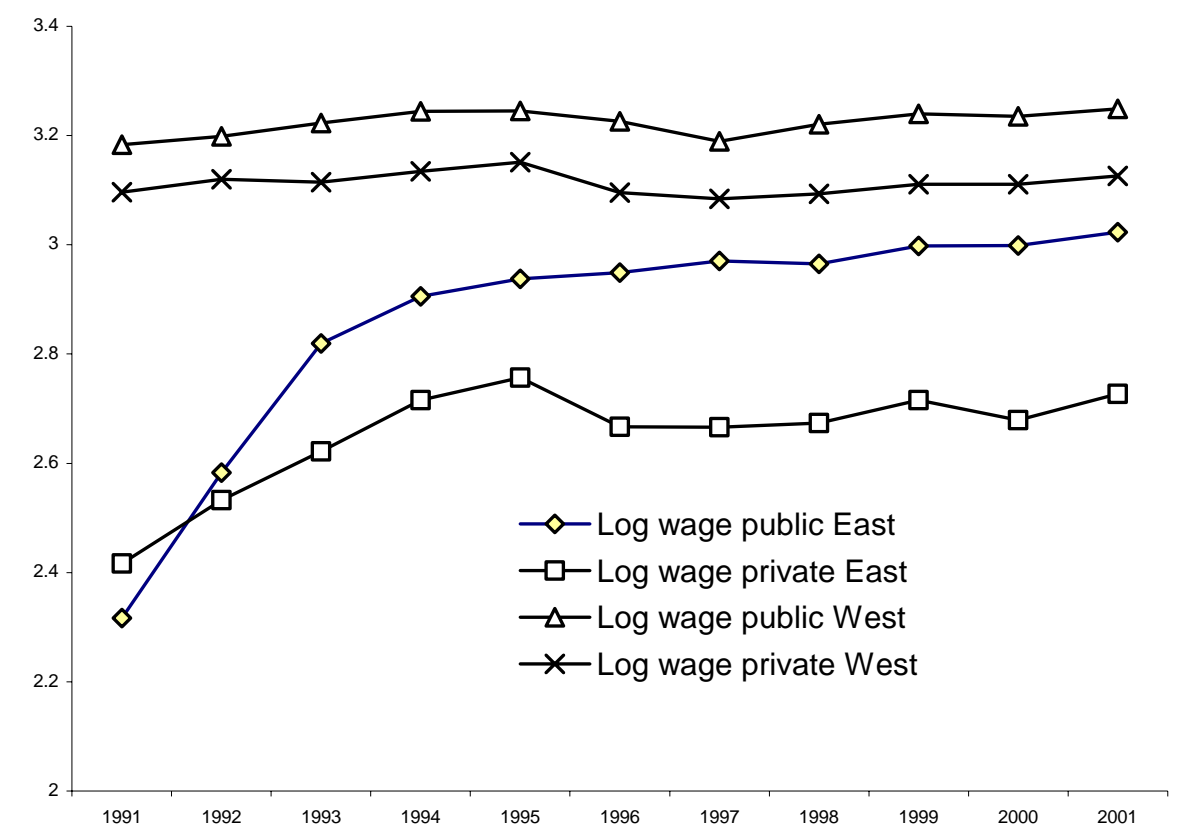

Note: Log hourly wages based on the GSOEP 1991-2001 (see text for definition)

Figure 1 shows the outcomes from these negotiations in terms of the log of hourly wages in the two sectors by region by year from 1991 to 2001. Vertical axis log-point differences amount roughly two percentage-point differences. The top two lines represent the West, showing very little movement in the real wages since reunification. The striking part of Figure 1 is the steep increases in real wages in the public sector in the East between the years 1991 to 1995. By contrast, the private sector in the East appears to have made some headway up to 1995 and none afterwards. Given the general low growth in the German economy in the 1990s, such large relative pay rises are clearly a cause for concern regarding their impact on the competitiveness of the former East Germany economy. The important policy question here is the degree to which the sharp increases in public sector wages in the East were the result of increased productivity, or the result of increased premium in that sector. Increases in productivity could be the result of the public sector taking advantage of the overall economic re-organisation of the regional labour markets in the East in order to hire better qualified employees, by "poaching” them from the private sector. Increases in the premium could be the result of differences in the way the public and private sector adjusted to above productivity wages set by mainly Western trade 
unions. It is difficult to distinguish between the two possibilities without using multivariate analysis.

\subsection{East-West convergence of wages by sector}

Observed wage convergence can be viewed as the joint outcome of market influences and institutional wage settlements. Figure 2 plots the development of East-West wage convergence by sector over time. Full convergence will have been achieved when the difference reaches zero (i.e. wages in the East and West are the same). Upon reunification, East wages in both sectors were much lower than West wages: the mean public (private) wage in the East was 12\% (31\%) of its West counterpart. Two main messages arise from Figure 2. First, most convergence happened in the first five years after re-unification. Second, the public sector appears to have converged considerably more than the private sector.

\section{Figure 2: Wage Gap convergence by sector}

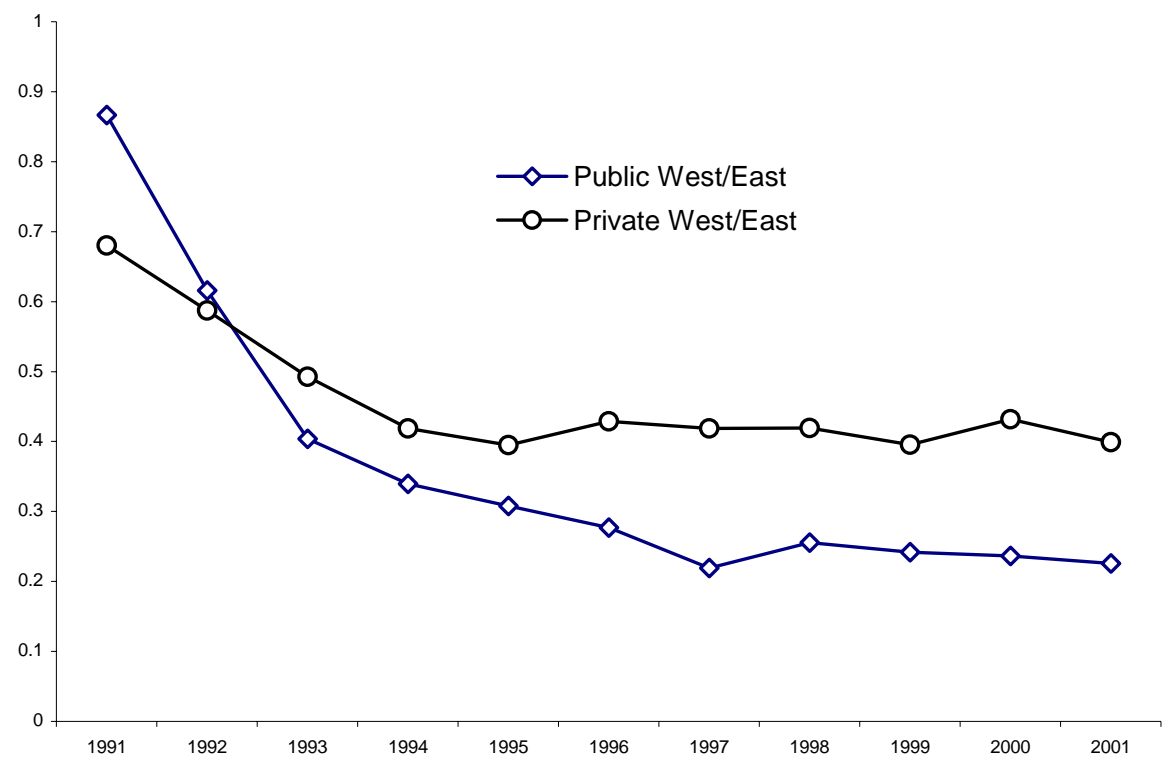

Note: Log hourly wages based on the GSOEP 1991-2001 (see text for definition)

The institutional background during this period of time is of interest.. The dominant role was played by institutional factors and these factors clearly favoured East-West convergence as a result of the political considerations discussed above. Hence, convergence reached very high levels by default, and given that the cost of living was cheaper in East Germany, one could argue that this convergence was highly 
successful in terms of its political remit. By contrast, private sector convergence was all but plain sailing. The competitiveness of the East private sector was clearly problematic. Market forces were exposing the problems in ways that created serious downwards wage pressures in the East, which were working against the stated political objective of East-West convergence. The extent to which market forces were working against convergence objectives became clearly obvious in 1995, when a large number of private sector firms in the East opted out of the national pay negotiations and started accepting lower wages, presumably in order to avoid further unemployment and/or bankruptcy (Hunt 1999). ${ }^{1}$ It is noteworthy that such pressures did not influence the relative position of public sector pay.

As mentioned above, unconditional (observed) mean wage differences cannot distinguish between the two competing explanations for these changes. After a brief presentation of the data in the next section, the paper presents and estimates a multivariate model which allows the analysis to distinguish between productivity and pay premium developments as the two causes of wage gap changes.

\section{The data}

The German Socio-economic Panel data (GSOEP) from 1991 to 2001 is used for estimations. Self employed, unemployed, labour market non-participants, individuals working for the armed forces or in agriculture and fishery are excluded from the sample. The data was split in two sub-sets, 1991-1995 and 1996-2001. The log of gross hourly wage is calculated using the monthly wage divided by the actual hours worked per week scaled up to actual hours worked per month. Actual hours per week also include overtime. The resulting gross nominal hourly wage is deflated by the CPI from the Statistisches Bundesamt to 2000 prices. Migrants have been excluded from the sample as they were treated differently in the East German and West German sub-

\footnotetext{
${ }^{1}$ It is indicative that in 1996 there was no difference between East and West in the coverage of employees by wage bargaining (around $90 \%$ for both regions). By contrast, only $50 \%$ of private employees were covered in the East compared with 65\% in the West (Franz \& Steiner 1999). It is clear that market forces influenced a small number of employees in the public sector, a higher proportion of employees in the private sector in the West and even higher proportion of employees in the private sector in the East.
} 
samples. Where values are missing from any of the variables used in the estimations, the observation is dropped. Regional dummies were used at the Laender level and much of the analysis splits the sample in East (Neue Bundeslaender) and West (Alte Bundeslaender), as well as males and females.

Table 1: Selected mean characteristics (1991-2001)

\begin{tabular}{lcccccc}
\hline & \multicolumn{2}{c}{ All } & \multicolumn{2}{c}{ East } & \multicolumn{2}{c}{ West } \\
& Public & Private & Public & Private & Public & Private \\
\hline Male & 0.4541 & 0.6230 & 0.3683 & 0.6117 & 0.5006 & 0.6290 \\
Female & 0.5459 & 0.3770 & 0.6317 & 0.3883 & 0.4994 & 0.3710 \\
Age & 40.14 & 38.14 & 40.18 & 38.43 & 39.98 & 38.01 \\
No education & 0.0212 & 0.0434 & 0.0038 & 0.0059 & 0.0310 & 0.0566 \\
Elementary education & 0.0756 & 0.1606 & 0.0272 & 0.0710 & 0.1009 & 0.1917 \\
Middle vocational & 0.4363 & 0.5685 & 0.4811 & 0.6627 & 0.4133 & 0.5372 \\
Vocational + Abitur & 0.0376 & 0.0508 & 0.0247 & 0.0311 & 0.0448 & 0.0576 \\
Higher vocational & 0.2066 & 0.0808 & 0.2460 & 0.1291 & 0.1840 & 0.0643 \\
Higher education & 0.2227 & 0.0959 & 0.2171 & 0.1003 & 0.2260 & 0.0925 \\
Log hourly wage & 3.11 & 3.00 & 2.90 & 2.67 & 3.23 & 3.11 \\
East & 0.3645 & 0.6355 & & & & \\
West & 0.2607 & 0.7393 & & & & \\
Sample size & 15757 & 41727 & 5743 & 10877 & 10014 & 30850 \\
\hline Note: GSOEP, for & sample & & & & &
\end{tabular}

Note: GSOEP, for sample definition see text.

Table 1 reports selected mean characteristics for the period 1991 to 2001 by sector and geographical distribution. Unsurprisingly, women are more likely to be employed in the public sector compared to men. However, this is driven by the East German public sector; in the West men are more likely to be found in both public and private sector. Age differences between the sectors are minute with slightly older employees in the East.

As expected, education varies both in terms of sector and geographical region. While there are very few people with no education in the East, almost 5 percent of private employees in the West have not even an elementary education. Regardless of the sector and region, the majority has at least a middle vocational education level. However, the percentage of employees with either higher vocational or higher education is much greater in the public sector raising the possibility of skill crowdingout by this sector (Dustmann and van Soest, 1997). ${ }^{2}$

Furthermore, log hourly wages are significantly higher in the public than in the private sector. This is particularly pronounced for East Germany with an overall gap

\footnotetext{
${ }^{2}$ For a formal discussion on public sector crowding-out see e.g. Henley and Thomas (2001)
} 
of almost $20 \log$ percentage points which is about twice as high as in the West. However, as shown in figure 1, the gap varies quite substantially when dividing the sample in the two periods 1991 to 1995 and 1996 to 2001.

Finally, the percentage of public employees is higher in the East compared with the West, although this difference was somewhat reduced in 2001. In 1991 in the East (West) 37\% (27\%) of employees were in the public sector. This percentage had been reduced to 30\% for the East and 24\% for the West by the year 2001 .

\section{The Model}

\subsection{Decompositions of the Public-Private wage gap.}

The paper estimates the following conventional panel earnings model

$$
\ln \left(\tilde{W}_{S R t i}\right)=\bar{X}_{S R t i}^{\prime} \beta_{S R}+\alpha_{S R i}+\varepsilon_{S R t i}
$$

where $R$ denotes the region (East or West), S denotes the sector (Public, Private, Pooled), $t$ the time period and $i$ the individual. In order to decide between a fixed effects (FE) and a random effects (RE) estimator, Model 1 is estimated and a Hausman test is carried out. The test rejects the RE estimation in favour of the FE estimation. $^{3}$

The estimation results presented here have been obtained using FE estimation at the individual level. Eight sub-samples are estimated in order to calculate the publicprivate pay gap in East(West) pre(post)-1995 Germany. ${ }^{4}$ The results of these estimations are then used to decompose the pay gap into its constituents: the explained part of the gap and the unexplained part of the gap. Omitting the subscripts for region, time and individual, the wage gap between the Public and Private sectors can be decomposed as follows:

\footnotetext{
${ }^{3}$ In all estimated specifications both the Breusch and Pagan test for heteroscedasticity and the Hausman test have been rejected at a 5 \% level.

${ }^{4}$ As this paper uses the decomposition method proposed by Oaxaca \& Ransom (1994) it also uses four pooled estimations where both private and public employees are estimate together in order to derive the benchmark pay structure used subsequently for the decompositions.
} 


$$
\begin{aligned}
& \ln \left(W_{P U B}\right)-\ln \left(W_{P R I V}\right)=\bar{X}_{P U B}^{\prime}\left(\hat{\beta}_{P U B}-\hat{\beta}_{P O O L}\right)+\bar{X}_{P R I V}^{\prime}\left(\hat{\beta}_{P O O L}-\hat{\beta}_{P R I V}\right) \\
& +\left(\bar{X}_{P U B}^{\prime}-\bar{X}_{P R I V}^{\prime}\right)^{\prime} \hat{\beta}_{P O O L}
\end{aligned}
$$

The convention behind decomposing a wage gap between its explained and unexplained parts runs as follows. The explained part of the gap refers to the pay gap that can be accounted for by differences in human capital (observed) characteristics between the two sectors. The unexplained part of the gap (often referred to as the public sector pay premium) refers to the part of the pay gap that cannot be accounted for by any observed characteristics. A moot point in such decompositions is whether the difference in the estimated constant term belongs to the explained or the unexplained part of the wage gap.

Generally, the fixed effects estimation is designed to account for unobserved timeinvariant differences in the data. This is done through estimating not the absolute levels of variables but their deviation from their mean by individual. As a result all individual time-invariant characteristics are swept away removing any bias that systematic unobserved heterogeneity may have caused. Sample selection may be a concern in the current context for at least two reasons. First, public sector choice may not be random (e.g. Hartog and Oosterbeek, 1993, Dustmann and van Soest, 1997, and Heitmueller, 2005). Secondly, productivity adjustments within sectors as a response to excessive wage levels in the East may have let to a selection of the most productive workers while others have been made redundant to help reducing the gap between actual productivity and set wages (Burda and Schmidt, 1997). It seems plausible that a large part of this selection is the result of time-invariant unobserved heterogeneity such as risk behaviour and ability. Hence, the fixed effects model deals explicitly with this type of selection and eliminates it. Unfortunately, this is done at the expense of losing the ability to produce estimates for any variable which is constant during the whole observation period for all individuals.

A major implication of the use of FE estimation in decomposition analysis is the way decompositions are interpreted. In general, an estimate is designed to answer the question of "how much $y$ (the dependent variable) may be influenced by a unitary change in $x$ (the explanatory variable)". By construction, a FE estimate is designed to 
address a more specific question, namely, "how much $y$ (the dependent variable) may be influenced by a unitary change in $x$ (the explanatory variable) where $x$ is measured in deviations from an individual mean in a time-series manner. In other words, explanatory variables do not measure all differences in the level of that variable in the whole sample (that would be both cross-section and time-series differences in a panel data set), they only measure changes in the level of that variable within the time-series history of each individual in the data set. Hence, the estimated effects refer to how changes within individuals affect wages. The degree to which cross section and time invariant differences between individuals may influence wages is not directly estimated in a FE context, as all such effects are included together in the individual specific fixed effect which is cancelled out when the data is differenced. ${ }^{5}$

\section{Estimation results, decompositions and discussion}

\subsection{General estimation results}

Equation 1 was estimated 12 times: by sector (public, private and pooled), region (East and West) and by time period (1991-1995 and 1996-2001). The dependent variable is log hourly wages. We control for marital status, firm size, occupation, job tenure, house ownership, children, education, age, region, and year. All estimations contained the same explanatory variables in order to make them comparable for the decompositions which used Equation 2 to decompose the wage gap. ${ }^{6}$ The specification used for Equation 1 is rather conventional.

Results largely accord with intuition. Getting married seems to make no difference in the private sector in the West, but appears to be beneficial in the public sector. The effect is similar in the East, only here the private sector penalises getting married whilst the public sector is indifferent. Large private firms pay more in both East and West. Size does not matter in the public sector, presumably due to more widely applied pay scales. Switching into or out of part time leaves pay unaffected in the

\footnotetext{
${ }^{5}$ There are certain unresolved issues in the literature regarding the consistency of decompositions based on Fixed Effects estimates which include time-invariant explanatory variables. .For an exposition see Heitmueller 2005. Splitting the sample, as has been done in this paper, party obviates the problem.

${ }^{6}$ Detail estimation tables for all models can be obtained from the authors upon request.
} 
private sector. By contrast switching into (out of) part time in the public sector increases (decreases) pay in the public sector. The impact of number of children by age is very patchy to draw any conclusions. There is some weak evidence that both sectors face children (or rather their effect on the quality and quantity of labour supply) in a negative fashion, more so the private than the public sector. The effect of education on earnings is, as expected, unambiguously positive and strong. Similarly, age has the expected quadratic effect on earnings, more so in the public sector. The regional dummies used (at the Laender level) showed very little significance, as did the time dummies. .

\subsection{Decompositions}

Results were decomposed in accordance with Equation 2 and categorised following the arguments of the previous section. Decomposition results were bootstrapped in order to establish their statistical significance.

Table 2: Oaxaca-Ransom Decompositions of Public-Private Pay Differential

\begin{tabular}{lllll}
\hline & \multicolumn{2}{c}{ East } & \multicolumn{2}{c}{ West } \\
& $1991-1995$ & $1996-2001$ & $1991-1995$ & $1996-2001$ \\
\hline Mean log wage gap & $0.0877^{*}$ & $0.2950^{*}$ & $0.1004^{*}$ & $0.1260^{*}$ \\
Explained & $0.1077^{*}$ & $0.1193^{*}$ & $0.1050^{*}$ & $0.1062^{*}$ \\
Unexplained & -0.0201 & $0.1757^{*}$ & -0.0046 & $0.0198^{*}$ \\
\hline
\end{tabular}

Note: Decompositions derived from fixed effects estimates controlling for time-invariant individual unobserved heterogeneity. * refers to $5 \%$ significance level based on bootstrapping with 500 repetitions.

Table 2 presents the decompositions of the public-private mean log wage gap.

Differences are in log points which correspond roughly to percentage points. The regional split of public-private pay differentials is clear.

The public-private pay gap in the West: The average public-private pay gap is close to 10\% between 1991 and 1995 and 13\% between 1996 and 2001. Most of it is due to observed (explained) differences in the human capital characteristics of the employees in the two sectors. Estimates do not suggest that there is a public sector premium in this part of Germany in the early 1990's and only a small premium in the late 1990's.

\footnotetext{
${ }^{7}$ Note that STATA (C xtreg was used to carry out Fixed Effects estimation. In order to identify the model STATA (C) assumes that the individual effects are zero on average. This assures that coefficients can be interpreted in the usual way i.e. as percentage changes in the log wages.
} 
This result supports the view that the wage setting process in the public sector in Germany follows quite closely that of the private sector (Dustmann and Soest 1997) and is thus indirectly subjected to market forces. The estimates of the public sector premium (the unexplained part of the gap) are small and not statistically significantly different from zero throughout the 1990s. Privatisation in the mid 1990s does not appear to have influenced the size of the pay gap either, giving further indirect support to the view that the public sector had already followed the private sector, so that privatisation made no great difference to the overall picture of wages.

The public-private pay gap in the East: The situation in the East is more complex, principally due to re-unification effects on firm ownership and the explicit political drive to raise wages towards an East-West economic convergence. It is mainly the latter that makes the notion of earnings premium in this context a difficult one given that private wages were well above market rates. Hence, any pay gap between the public and private sector cannot be strictly interpreted in the usual way but, possibly, merely as a measure of the relative differences in earnings and actual productivity. Estimates from the 1991-1995 show that there is a public-private pay gap of around $9 \%$, all of which is due to observed (explained) human capital differences. The picture is very similar to that in the West. By contrast, estimates from the 1996-2001 period show great differences between East and West: the overall gap has increased from $8.77 \%$ to almost threefold $29.5 \%$. None of this change is due to changes in the human capital composition of the two sectors. It is all due to the change in the unexplained gap (the public sector premium) which increased from $-2 \%$ to $+17 \%$. One possible explanation for this result may be that the convergence objective could not be sustained by the private sector wage due to adverse market forces, but could be sustained by the public sector which were less exposed to the direct influence of market forces.

Various other model specifications have been run to test the robustness of the results. For example, yearly decompositions have been estimated and the evidence in trends agrees very much with the above results. Also, we have used overlapping five year panels to decompose the public private sector gap and again the above results are confirmed. 


\section{The gender dimension of the public-private pay gap}

For this section Equation 1 was estimated further 24 times: by sector (public, private and pooled), region (East and West) and by time period (1991-1995 and 1996-2001) and by gender (male and female). Equation 1 and Decomposition 2 were then applied separately to the male and female sub-samples in the data. Results reported in Table 3 are considerably different by gender and worth visiting.

Table 3: Oaxaca-Ransom Decompositions of Public-Private Pay Differential

\begin{tabular}{lcccc}
\hline & \multicolumn{2}{c}{ East } & \multicolumn{2}{c}{ West } \\
& $1991-1995$ & $1996-2001$ & $1991-1995$ & $1996-2001$ \\
\hline \multirow{3}{*}{ Mean log wage gap } & 0.0275 & 0.2588 & 0.0859 & 0.1225 \\
Explained & $0.2315^{*}$ & $0.1385^{*}$ & $0.1098^{*}$ & $0.1252^{*}$ \\
Unexplained & $-0.2039^{*}$ & $0.1202^{*}$ & -0.0239 & -0.0027 \\
& \multicolumn{3}{c}{ Females } & \\
Mean log wage gap & $0.2059^{*}$ & $0.3740^{*}$ & 0.1943 & 0.2108 \\
Explained & 0.0702 & $0.1007^{*}$ & $0.1199^{*}$ & $0.0968^{*}$ \\
Unexplained & $0.1356^{*}$ & $0.2733^{*}$ & $0.0744^{*}$ & $0.1140^{*}$ \\
\hline
\end{tabular}

Note: Decompositions derived from fixed effects estimates controlling for time-invariant individual unobserved heterogeneity. * refers to 5\% significance level based on bootstrap with 500 repetitions.

Comparing Tables 2 and 3 suggests that overall effects in Table 2 conceal substantial gender differences in the public-private pay gap and its decomposition. Table 3 rectifies this by presenting separate estimates by gender. The most striking difference between Tables 2 and 3 is the presence of a male private sector and female public sector pay premium in the 1991-95 post-unification period. Again it is very difficult to refer to the unexplained part as a earnings premium in the standard sense. Usually the base category (private sector) is considered to pay at market rate. However, this has most certainly not been the case in East Germany. Hence, both public and private sector are likely to have paid above productivity rates. It is interesting that results suggest that in the 1991-95 East Germany public sector the gap between wage and productivity was large and positive (13.6\%) for females, and large and negative (20.4\%) for males. The male premium reverses sign in the 1996-2001 period becoming $12.0 \%$. Still, however, the male-female differences remain considerable as females exhibit a more than double $27.3 \%$ premium for the 1996-2001 period. In the West, male-female differences are more stable over time, but the public sector pay premium 
is clearly only enjoyed by females. Indeed, there appears to be no public sector pay premium for males at all (estimates for both periods are not statistically significant). Several interesting observations can be made regarding the relationship between the male-female gap and the public-private pay gap. First, it is clear that gender differences in total and decomposed pay gap may have been the result of different gender structures by sector (Table 1) as well as differences in labour demand shortly after re-unification. With a differential rate of gender participation in the two sectors and a differential exercise of national versus local wage settlements between publicprivate and East-West during the investigation period, there are bound to be substantial gender-related effects of post-reunification convergence policies. Second, as it turns out in this instance, the increase of the public sector pay premium observed in the East is not all bad news. Although it could be the result of pay beyond marginal product (thus introducing market inefficiency) it is bound to have contributed to a reduction in the unexplained part of male-female pay gap (thus reducing market inefficiency). It is clear that gender and sector pay gaps are very closely connected. Although further research in the simultaneous determination of the gender and the sector pay gaps could be extremely interesting, it lies beyond the scope of this paper.

\section{Conclusion}

This paper examined the development of the public-private sector pay gap in postreunification Germany from 1991 to 2001. Results suggest that the political efforts for an East-West convergence of earnings dominated the relative development of earnings in East Germany in the 1990s. Both sectors converged in a largely similar fashion between 1991 and 1995 but at different levels. From 1996 onwards, the private sector slowed down, being subjected to intense market forces. By 2001, the end of the observation period in this paper, the private sector in the East had only managed to achieve mean wages of $40 \%$ less than their West counterparts. By contrast, the public sector continued to converge throughout the 1990s and had achieved a mean pay in the East that was only 20\% lower than its West counterpart. The decompositions of the public-private pay gap revealed that a substantial part of the public sector convergence can be attributed to a public sector premium in the East 
which may reflect the gap between pay and actual productivity as a result of political equality consideration. Whether this development will disturb the finely balanced preunification pay settlement practices remains to be seen. Further investigation revealed that most of the public sector premium in the East was enjoyed by female employees, thus addressing, at least in part, the long standing issue of a positive male-female wage gap. 


\section{References}

Burda, M.C. and Ch.M. Schmidt (1997), Getting behind the East-West Wage

Differential. Theory and Evidence. In R. Pohl and H. Schneider (eds.), Wandeln oder weichen: Herausforderungen der wirtschaftlichen Integration für Deutschland. IWHHalle, 170-201.

Dustmann C. and van Soest A. (1997) Wage Structures in the Private and Public Sectors in West Germany. Fiscal Studies 18, 225-247.

Dustmann C. and van Soest A. (1998) Public and private sector wages of male workers in Germany. European Economic Review 42, 1417-1441.

Franz W. and Steiner V. (1999) Wages in the East German Transition Process - Facts and Explanations. Mimeo ZEW

Hartog, J. and Oosterbeek, H. (1993) Public and private sector wages in the Netherlands. European Economic Review 37, 97-114

Heitmueller, A. (2005) Public-Private Sector Pay Differentials in a Devolved Scotland. Forthcoming

Heitmueller, A. (2005) A Note on Decompositions in Fixed Effects Models in the Presence of Time-Invariant Characteristics. Forthcoming

Henley A. and Thomas D. (2001) Public Service Employment and the Public-Private Wage Differential in British Regions. Regional Studies 35, 229-240.

Hunt J. (1999) Post-Unification Wage Growth in East Germany. NBER Working Paper No 6878

Oaxaca R. L. and Ransom M. R. (1994) On discrimination and the decomposition of wage differentials. Journal of Econometrics 61(1) 5-21

Sinn H.-W. (1995) Staggering along: wages policy and investment support in East Germany. Economics of Transition 3, 403-426.

Steiner V. (2001) How is Germany's labour market coping with unification? Mimeo ZEW 